\title{
How Much Do Trading Partners Matter for Economic Growth?
}

\author{
VIVEK ARORA and ATHANASIOS VAMVAKIDIS*
}

This paper empirically examines the extent to which a country's economic growth is influenced by the economies of its trading partners. Panel estimation results based on four decades of data for more than 100 countries show that trading partners' growth has a strong effect on domestic growth, even after controlling for the influence of common global and regional trends. The results are robust to instrumental variable estimation and other robustness tests. Trading partners' relative income levels are also positively correlated with growth, suggesting that the richer a country's trading partners, the stronger is conditional convergence. A general implication of the results is that countries benefit from trading with fast-growing and relatively more developed countries. [JEL F43, F15]

H ow much does a country's long-term economic growth depend on economic conditions in the rest of the world? The view is commonly held that with growing economic integration across countries, economic developments in a country are significantly influenced by developments abroad. ${ }^{1}$ In addition, barring some notable objections, the general conclusion in the literature is that trade openness has a positive impact on growth. ${ }^{2}$ However, the quantification of the relationship

\footnotetext{
* Vivek Arora is the IMF resident representative in South Africa and Lesotho; Athanasios Vamvakidis is the IMF resident representative in Croatia. The authors are grateful to Tamim Bayoumi, Michael Clemens, Gian-Maria Milesi Ferretti, Robert Flood, Olivier Jeanne, Se-Jik Kim, Thomas Krueger, Paolo Mauro, Guy Meredith, James Morsink, Jonathan Ostry, Doris Ross, Antonio Spilimbergo, and three anonymous referees for helpful comments. The authors are solely responsible for the contents of the paper.

${ }^{1}$ See, for example, The Economist (2002).

${ }^{2}$ See Baldwin (2003) for a review of the literature.
} 
between foreign economic conditions and domestic economic growth has been relatively neglected in the literature.

This paper shows empirically that economic conditions in trading partner countries matter for growth. In particular, a country's economic growth is positively influenced by both the growth rate and the relative income level of its trading partners, after controlling for other growth determinants. A general implication of the results is that countries benefit from trading with fast-growing and relatively richer countries. The paper tries to capture the strength of this impact over the long run.

An analysis using panel data for the period 1960-1999 for 101 industrial and developing economies suggests that a 1 percentage point increase in economic growth among a country's trading partners (keeping all else equal) is correlated with an increase in domestic growth of as much as 0.8 percentage points. This positive correlation is consistent with the conclusions of the trade and growth literature, as well as with those of a few recent papers that have tried to quantify the impact of cross-country growth spillovers. ${ }^{3}$ However, the relationship is stronger than one might have expected. In addition, the level of foreign income relative to domestic income matters for growth, in the sense that the ratio of the average per capita GDP of trading partners relative to a country's own per capita GDP is positively correlated with growth. One interpretation of this result is that the richer a country's trading partners, the stronger is conditional convergence.

The results seem to be stronger for more open economies and for more recent decades (1980-1999), although this is sensitive to model specification. They remain robust when we control for global and regional growth trends. The results are also robust to estimation that uses regional growth to instrument for growth in trading partners, addressing any potential causality concerns, and to a number of other robustness tests: estimation with or without fixed effects, alternative time periods, cross-section estimation, estimation using longer-period averages, and estimation separating open and closed economies.

There is some debate in the growth-openness literature as to whether trade with less developed countries is beneficial for growth. Some models suggest that growth is positively influenced by trade with less developed countries because it leads to specialization in relatively advanced sectors. But some papers suggest that this conclusion may depend on specific model assumptions. ${ }^{4}$ This paper argues that, in practice, the net impact on a country's growth of trading with relatively less developed countries is an empirical question: The impact is negative if the relative income effect dominates and positive if the relative growth effect dominates.

An important element in empirical analyses of trading partner data is the use of appropriate trade weights. In particular, if the relative importance of a country's trading partners changes over time, these changes will not be captured accurately

\footnotetext{
${ }^{3}$ For example, Arora and Vamvakidis (2004) find a positive relationship between long-run growth in the United States and in the rest of the world, which they attribute to the importance of the United States as a global trading partner, and Ahmed and Loungani (1999) find that the short-run impact of foreign output shocks on domestic output in emerging market economies is roughly one-for-one.

${ }^{4}$ Spilimbergo (2000) provides a discussion of such models and argues that, in principle, a rich country could be worse off by trading with a poor country whose demand pattern is biased toward sectors that have weak learning-by-doing effects.
} 
by trade weights based on a fixed point in time. With this in mind, a time series of trade weights was estimated for each country in the sample for the period 1960-1999 and was used in the analysis. ${ }^{5}$ In terms of key global trading partners, as of the late 1990s, the United States was among the 10 most important partners for 90 countries; other important trading partners were the United Kingdom, Germany, the Netherlands, France, Italy, and Japan.

\section{Empirical Literature on the Growth-Openness Connection}

Many studies have documented a positive relationship between openness and growth. ${ }^{6}$ Dollar (1992); Barro and Sala-i-Martin (1995); Sachs and Warner (1995); Edwards (1998); Greenaway, Morgan, and Wright (1998); and Vamvakidis (1998) report cross-country regression results showing that trade protection reduces growth rates. ${ }^{7}$ Ben-David (1993) and Sachs and Warner (1995) show that only open economies experience unconditional convergence. Coe and Helpman (1995) and Coe, Helpman, and Hoffmaister (1997) provide evidence of positive spillover effects on growth from research and development (R\&D) activities in trading partner countries. Frankel and Romer (1999) provide instrumental-variable estimates using geographic characteristics that confirm a significant and robust positive impact of trade on growth. Brunner (2003) extends the cross-country Frankel and Romer methodology to a panel estimation and finds a significant positive impact of trade on income. Harrison (1996) and Vamvakidis (1999) report fixed-effects estimation results similar to those from the cross-country regressions cited above.

The debate continues regarding some of the results reported in the literature. Rodriguez and Rodrik (1999) challenge the robustness of the openness-growth correlation found by Dollar (1992), Ben-David (1993), Sachs and Warner (1995), and Edwards (1998), arguing that some of these studies do not control for other important growth determinants and that shortcomings exist in the openness measures that are used. However, Warner (2002) questions the Rodriguez and Rodrik (1999) argument and presents results that reestablish the positive growthopenness link. ${ }^{8}$ Vamvakidis (2002) and Clemens and Williamson (2004) examine

\footnotetext{
5 The estimates are based on trade flow data from the IMF's Direction of Trade Statistics (IMF, 2002). It turns out that trade weights are highly correlated over time for both developing and industrial countries, which suggests that countries do not often change their trading partners. However, it is more meaningful to use current weights rather than weights based on trade flows during a dated, and possibly arbitrary, base period.

${ }^{6}$ For a discussion of the early empirical and theoretical trade and growth literature, see Bhagwati and Srinivasan (1985). For more recent literature reviews, see Greenaway, Morgan, and Wright (1998); Bhagwati and Srinivasan (2002); and Baldwin (2003).

${ }^{7}$ Barro and Sala-i-Martin (1995) find that tariff rates have a significant negative impact on growth, although the impact of nontariff barriers is not statistically significant.

${ }^{8}$ Specifically, Sachs and Warner (1995) use a composite measure of openness, while Rodriguez and Rodrik (1999) disaggregate the measure and find that only the component relating to the black market premium is significant in a growth regression. They claim that this premium has to do with macroeconomic stability rather than trade protection. However, Warner argues that the black market premium may, in fact, reflect trade distortions and that most powerful tests of the growth-openness connection come from aggregating various measures of protection.
} 
longer-period historical data and find that the correlation between openness and growth becomes significant only in recent decades, which could suggest that a relatively open world economy is required for trade to have a positive impact on growth.

This paper addresses a question that is relatively unexplored in the growthopenness literature: it focuses on how much economic conditions among trading partners matter for growth rather than on whether and how much openness in general matters. Economic conditions abroad, including both growth rates and income levels, could be expected to have an impact on growth through channels such as aggregate demand effects and technological spillovers. Clemens and Williamson (2004) were the first to include growth of trading partners in a growth regression, using historical data for the period 1869-1999 for 35 countries. The estimate turned out to be insignificant in both economic and statistical terms, which the authors noted was surprising. In this paper the focus is on a more recent period, which allows for the inclusion of a considerably larger number of countries in both the sample used in the regressions and the sample of trading partners, and for the control of a larger number of independent variables.

\section{Trading Partners}

The first step in attempting to quantify the impact on growth of economic conditions among trading partners is to construct trade weights that can be used to calculate weighted average growth rates and income levels of each country's trading partners. The analysis below uses export weights - that is, each trading partner's share of the country's total exports 9 - for which a time series is constructed using data from the IMF's Direction of Trade Statistics (DOTS) (IMF, 2002) for the period 1960-1999.

The data reveal a few interesting facts. First, the relative importance of a country's trading partners does not change much, as reflected in a high correlation of trade weights across time. Specifically, from 1960 through 1999, the correlation between trade weights in successive 5-year periods is 0.93 ; for successive 10 -year periods, it is $0.88 .{ }^{10}$ Second, for most countries, the set of most important trading partners remains relatively stable over time. ${ }^{11}$ Half of the countries that were among the 10 most important trading partners for other countries in the early 1960s were also on this list in the late 1990s (Table 1).

Third, countries that trade with relatively rich countries (in terms of per capita GDP) in one decade trade with relatively rich countries in the next decade, too; likewise for relatively poor countries. The difference between the average level of trading partners' per capita GDP for industrial and developing countries during

\footnotetext{
${ }^{9}$ The average share over a five-year period is used, as annual shares tend to be volatile.

${ }^{10}$ The correlation for the whole period (that is, between trade weights in the first half of the 1960s and the second half of the 1990s) is 0.70. It is somewhat higher for industrial than for developing countries (0.88 and 0.66 , respectively).

${ }^{11}$ This stability is somewhat surprising, given the increase in international integration during this period.
} 


\begin{tabular}{|c|c|c|c|}
\hline \multicolumn{2}{|c|}{$1960 \mathrm{~s}$} & \multicolumn{2}{|c|}{$1990 \mathrm{~s}$} \\
\hline & Countries & & Countries \\
\hline United States & 84 & United States & 90 \\
\hline United Kingdom & 82 & Germany & 83 \\
\hline Germany & 80 & United Kingdom & 79 \\
\hline Netherlands & 78 & Netherlands & 73 \\
\hline France & 65 & France & 68 \\
\hline Italy & 65 & Italy & 65 \\
\hline Japan & 50 & Japan & 57 \\
\hline Sweden & 36 & Spain & 47 \\
\hline Australia & 27 & Belgium & 39 \\
\hline Canada & 27 & Korea & 24 \\
\hline Spain & 22 & China & 20 \\
\hline Argentina & 21 & Singapore & 19 \\
\hline Denmark & 21 & Hong Kong SAR & 18 \\
\hline Switzerland & 20 & Canada & 16 \\
\hline Brazil & 19 & Portugal & 16 \\
\hline Austria & 18 & Switzerland & 15 \\
\hline India & 14 & India & 13 \\
\hline Norway & 13 & Thailand & 13 \\
\hline Benin & 12 & Malaysia & 12 \\
\hline China & 12 & Brazil & 11 \\
\hline
\end{tabular}

this period is very small. ${ }^{12}$ The list of the top and bottom performers in terms of trading partners' growth changes over time (Table 2), although trading partners' growth performance is roughly the same for industrial and developing countries. Fourth, the data indicate that the most important trading partners for other countries have been the United States, followed by the United Kingdom, Germany, the Netherlands, France, Italy, and Japan. ${ }^{13}$

\section{Empirical Approach and Results}

\section{Methodology}

The impact of trading partners' growth on domestic growth can be quantified by estimating a fixed-effects panel regression, which allows an analysis of a cross section of countries over time. The fixed-effects estimator allows the constant term to differ across cross-section units and captures the time-series dimension of the trading partners' growth effect, after controlling for other growth determinants.

\footnotetext{
${ }^{12}$ The per capita GDP is only \$283 higher in 1995 constant values for industrial countries.

${ }^{13}$ The United States has been the most important trading partner during the past four decades. It was among the 10 most important trading partners for 90 countries in the late 1990s, up from 84 countries in the early 1960s.
} 


\begin{tabular}{|c|c|c|c|}
\hline \multirow[b]{2}{*}{$1960 \mathrm{~s}$} & \multicolumn{3}{|c|}{$\begin{array}{c}\text { Economies Ranked by Their Trading Partners' } \\
\text { Per Capita GDP Growth }\end{array}$} \\
\hline & $1970 \mathrm{~s}$ & $1980 \mathrm{~s}$ & $1990 \mathrm{~s}$ \\
\hline \multicolumn{4}{|c|}{ The 10 Economies with the Fastest-Growing Trading Partners } \\
\hline Malaysia & Guinea-Bissau & China & China \\
\hline Guinea-Bissau & Malaysia & Malaysia & Singapore \\
\hline Saudi Arabia & Indonesia & Indonesia & Malaysia \\
\hline Philippines & Jordan & Singapore & Japan \\
\hline Korea & Thailand & Hong Kong SAR & Thailand \\
\hline Indonesia & Mauritania & Australia & Indonesia \\
\hline Nicaragua & Syrian Arab Rep. & Nepal & Korea \\
\hline Australia & Saudi Arabia & Philippines & Australia \\
\hline Mozambique & Singapore & Papua New Guinea & Pakistan \\
\hline Syrian Arab Rep. & Pakistan & Thailand & Jordan \\
\hline
\end{tabular}

The 10 Economies with the Slowest-Growing Trading Partners

$\begin{array}{llll}\text { Grenada } & \text { Costa Rica } & \text { Bolivia } & \text { Burkina Faso } \\ \text { China } & \text { Dominican Republic } & \text { South Africa } & \text { Burundi } \\ \text { Malawi } & \text { Samoa } & \text { Burkina Faso } & \text { South Africa } \\ \text { Mauritius } & \text { Kenya } & \text { Jordan } & \text { Niger } \\ \text { Ireland } & \text { Bolivia } & \text { Guatemala } & \text { Zimbabwe } \\ \text { Zimbabwe } & \text { Trinidad and Tobago } & \text { Mali } & \text { Malawi } \\ \text { Barbados } & \text { Chad } & \text { Paraguay } & \text { Austria } \\ \text { Sierra Leone } & \text { Malawi } & \text { Senegal } & \text { Mauritania } \\ \text { Burkina Faso } & \text { Ecuador } & \text { Cyprus } & \text { Syrian Arab Rep. } \\ \text { Bolivia } & \text { Sierra Leone } & \text { Costa Rica } & \text { Poland }\end{array}$

Source: IMF, Direction of Trade Statistics (2002); and World Bank, World Development Indicators (2002).

The robustness of the results can be tested by excluding the fixed effects in a pooled panel estimation. Also, unlike a cross-country regression using long-period average data, a panel regression provides additional information since it captures both time-series and cross-sectional information. Furthermore, with a fixed-effects panel approach, it is possible to control for other explanatory variables and changes in them over time, and to test the robustness of the trading partners' estimated growth impact to changes in model specification.

While a fixed-effects panel approach is preferable for analyzing long-run growth, a few recent studies use alternative methodologies to analyze the impact of foreign output fluctuations on domestic business cycles. Ahmed and Loungani (1999) use a vector-error-correction model to estimate the impact of foreign output shocks on domestic output for several emerging market economies. They find the impact to be roughly one-for-one, after controlling for other shocks. Agenor, McDermott, and Prasad (1999) estimate cross-correlations using seasonally adjusted and detrended quarterly data to determine the stylized facts of business cycles in developing countries; they find that output fluctuations in industrial countries are transmitted with near-zero lag to most developing countries. 


\section{Estimation}

The empirical framework is a growth regression with a specification that is standard in the literature: 14

$$
(\text { Real per capita GDP growth })_{i}=c_{i}+\beta X_{i}+u, \quad \text { for country } i=1, \ldots, n \text {. }
$$

The dependent variable is the average real per capita GDP growth rate; $c_{i}$ is the matrix of constant terms for each country $i$; $\beta$ is the matrix of parameters to be estimated; and $u$ is the error term. $X_{i}$ is the matrix of independent variables that includes the standard variables in growth regressions:

- Convergence (the logarithm of real per capita GDP in the initial year of the period under consideration); ${ }^{15}$

- Demographic developments (population growth);

- Investment in physical capital (gross domestic investment as a percentage of GDP);

- Human capital (secondary school enrollment);

- Macroeconomic stability (inflation); and

- Trade openness (share of external trade in GDP). ${ }^{16}$ In addition, $X_{i}$ includes:

- Trading partners' real per capita GDP growth;

- Ratio of domestic real per capita GDP to trading partners' real per capita GDP (and, in an alternative specification, trading partners' real per capita GDP); and

- Interaction terms with openness, to test whether economies that are more open benefit more from economic conditions in their trading partners.

Finally, to test whether results are driven by global or regional trends rather than by trends confined to trading partners, $X_{i}$ also includes:

- World real per capita GDP growth;

- Nontrading partners' real per capita GDP growth; and

- Distance-weighted real per capita GDP growth.

The distance-weighted growth variable is intended to capture the suggestion in the "gravity" model of trade that the amount of trade between two countries depends significantly on their distance from each other.

All data are from the World Development Indicators (World Bank, 2002), unless otherwise indicated. All countries with available data (101 countries) are included in the regressions. The time period is 1960-1999. Each observation is a five-year average, except the initial per capita GDP, which takes the value of the first year of each five-year period. The use of a fixed-effects rather than a randomeffects model is justified by a Hausman test, which rejects the hypothesis that the individual effects are uncorrelated with the other repressors for most specifications. The trading partners were determined by estimating weights based on DOTS

\footnotetext{
${ }^{14}$ See, for example, Barro and Sala-i-Martin (1995).

${ }^{15}$ Caselli, Esquivel, and Lefort (1996) have argued that the initial per capita GDP is endogenous. However, excluding it from the regressions in the present analysis did not change the conclusions.

${ }^{16}$ Although it has its drawbacks, the trade share is one of the most broadly used and robust measures of openness in the literature (see Levine and Renelt, 1992). A strong advantage of the trade share is that it varies over time.
} 


\begin{tabular}{|c|c|c|c|c|c|c|}
\hline Independent Variables & (1) & (2) & (3) & (4) & (5) & (6) \\
\hline ln (initial per capita GDP) & $\begin{array}{l}-1.66 \\
(-4.52)\end{array}$ & $\begin{array}{l}-3.70 \\
(-7.18)\end{array}$ & $\begin{array}{l}-3.66 \\
(-7.13)\end{array}$ & $\begin{array}{l}-3.75 \\
(-7.15)\end{array}$ & $\begin{array}{l}-3.66 \\
(-6.58)\end{array}$ & $\begin{array}{l}-3.68 \\
(-7.33)\end{array}$ \\
\hline Population growth & & $\begin{array}{l}-0.27 \\
(-0.90)\end{array}$ & $\begin{array}{l}-0.29 \\
(-0.96)\end{array}$ & $\begin{array}{l}-0.25 \\
(-0.81)\end{array}$ & $\begin{array}{l}-0.34 \\
(-1.07)\end{array}$ & $\begin{array}{l}-0.20 \\
(-0.66)\end{array}$ \\
\hline Investment/GDP & & $\begin{array}{c}0.16 \\
(6.66)\end{array}$ & $\begin{array}{c}0.17 \\
(6.73)\end{array}$ & $\begin{array}{c}0.16 \\
(6.71)\end{array}$ & $\begin{array}{l}0.16 \\
(6.53)\end{array}$ & $\begin{array}{c}0.16 \\
(6.70)\end{array}$ \\
\hline Inflation rate & & $\begin{array}{l}-0.001 \\
(-2.14)\end{array}$ & $\begin{array}{l}-0.001 \\
(-2.24)\end{array}$ & $\begin{array}{l}-0.001 \\
(-2.17)\end{array}$ & $\begin{array}{l}-0.001 \\
(-2.16)\end{array}$ & $\begin{array}{l}-0.001 \\
(-2.17)\end{array}$ \\
\hline $\begin{array}{l}\text { Secondary school } \\
\text { enrollment }\end{array}$ & & $\begin{array}{c}0.03 \\
(2.49)\end{array}$ & $\begin{array}{c}0.03 \\
(2.62)\end{array}$ & $\begin{array}{c}0.02 \\
(1.66)\end{array}$ & $\begin{array}{l}0.03 \\
(2.27)\end{array}$ & $\begin{array}{c}0.03 \\
(2.40)\end{array}$ \\
\hline Trade/GDP & & $\begin{array}{c}0.03 \\
(2.78)\end{array}$ & $\begin{array}{c}0.03 \\
(2.78)\end{array}$ & $\begin{array}{l}0.02 \\
(2.52)\end{array}$ & $\begin{array}{l}0.02 \\
(2.65)\end{array}$ & $\begin{array}{c}0.01 \\
(0.85)\end{array}$ \\
\hline $\begin{array}{l}\text { Growth of trading partner } \\
\text { countries }\end{array}$ & $\begin{array}{l}0.60 \\
(5.71)\end{array}$ & $\begin{array}{c}0.82 \\
(7.08)\end{array}$ & $\begin{array}{c}0.73 \\
(5.51)\end{array}$ & $\begin{array}{l}0.84 \\
(7.20)\end{array}$ & $\begin{array}{c}0.69 \\
(5.33)\end{array}$ & $\begin{array}{c}0.38 \\
(1.93)\end{array}$ \\
\hline World per capita GDP growth & & & $\begin{array}{c}0.19 \\
(1.50)\end{array}$ & & & \\
\hline Time dummy & & & & $\begin{array}{l}0.06 \\
(0.76)\end{array}$ & & \\
\hline $\begin{array}{l}\text { Growth of nontrading } \\
\text { partner countries }\end{array}$ & & & & & $\begin{array}{c}0.17 \\
(1.89)\end{array}$ & \\
\hline Interaction term: & & & & & & 0.01 \\
\hline $\begin{array}{l}\text { Growth of trading partners } \\
\times \text { Trade/GDP }\end{array}$ & & & & & & $(2.49)$ \\
\hline Adjusted R-squared & 0.31 & 0.46 & 0.46 & 0.46 & 0.46 & 0.47 \\
\hline
\end{tabular}

(IMF, 2002), although all the results are robust to the use of alternative fixedperiod weights based on the early 1990s. The advantage of the DOTS weights is that they change annually to reflect evolving trade patterns. ${ }^{17}$

\section{Results}

The first and second regressions in Table 3 show that, even after controlling for other growth determinants, a 1 percent increase in growth among a country's trading partners is correlated with as much as a 0.8 percent increase in domestic growth. Thus, it pays to trade with fast-growing countries. The third, fourth, and fifth regressions show that this result is not driven by common global shocks, as the coefficient remains sizable (0.7) and significant even after controlling for world growth, for a time trend, and for growth in countries that are not trading partners. The last

\footnotetext{
${ }^{17}$ Although it would be interesting to test whether the composition of bilateral trade matters for growth, in the present specification this would require data on bilateral trade by sector for more than 100 countries over a 40-year period; to our knowledge, such data do not exist.
} 


\begin{tabular}{|c|c|c|c|c|}
\hline Independent Variables & (1) & (2) & (3) & (4) \\
\hline ln (initial per capita GDP) & $\begin{array}{l}-3.82 \\
(-7.25)\end{array}$ & $\begin{array}{l}-3.33 \\
(-6.31)\end{array}$ & $\begin{array}{l}-3.34 \\
(-6.48)\end{array}$ & $\begin{array}{l}-3.34 \\
(-6.29)\end{array}$ \\
\hline Population growth & $\begin{array}{l}-0.23 \\
(-0.75)\end{array}$ & $\begin{array}{l}-0.22 \\
(-0.72)\end{array}$ & $\begin{array}{l}-0.16 \\
(-0.53)\end{array}$ & $\begin{array}{l}-0.16 \\
(-0.50)\end{array}$ \\
\hline Investment/GDP & $\begin{array}{c}0.16 \\
(6.70)\end{array}$ & $\begin{array}{c}0.16 \\
(6.69)\end{array}$ & $\begin{array}{c}0.16 \\
(6.73)\end{array}$ & $\begin{array}{c}0.16 \\
(6.45)\end{array}$ \\
\hline Inflation rate & $\begin{array}{l}-0.001 \\
(-2.07)\end{array}$ & $\begin{array}{l}-0.001 \\
(-2.05)\end{array}$ & $\begin{array}{l}-0.001 \\
(-2.08)\end{array}$ & $\begin{array}{l}-0.001 \\
(-2.08)\end{array}$ \\
\hline Secondary school enrollment & $\begin{array}{c}0.02 \\
(1.61)\end{array}$ & $\begin{array}{c}0.02 \\
(1.91)\end{array}$ & $\begin{array}{c}0.02 \\
(1.87)\end{array}$ & $\begin{array}{r}-0.02 \\
(1.87)\end{array}$ \\
\hline Trade/GDP & $\begin{array}{c}0.02 \\
(2.48)\end{array}$ & $\begin{array}{c}0.02 \\
(2.81)\end{array}$ & $\begin{array}{c}0.01 \\
(0.94)\end{array}$ & $\begin{array}{c}0.01 \\
(0.92)\end{array}$ \\
\hline Growth of trading partner countries & $\begin{array}{c}0.83 \\
(7.27)\end{array}$ & $\begin{array}{c}0.82 \\
(7.04)\end{array}$ & $\begin{array}{c}0.40 \\
(2.04)\end{array}$ & $\begin{array}{l}0.40 \\
(2.05)\end{array}$ \\
\hline Per capita GDP of trading partners & $\begin{array}{c}0.68 \\
(1.36)\end{array}$ & & & \\
\hline $\begin{array}{l}\text { Ratio of per capita GDP to trading partners' } \\
\text { per capita GDP }\end{array}$ & & $\begin{array}{l}-1.45 \\
(-3.87)\end{array}$ & $\begin{array}{l}-1.29 \\
(-3.45)\end{array}$ & $\begin{array}{l}-1.28 \\
(-2.73)\end{array}$ \\
\hline Interaction term: & & & 0.01 & 0.01 \\
\hline Growth of trading partners $\times$ Trade/GDP & & & $(2.34)$ & (2.34) \\
\hline Interaction term: & & & & -0.00 \\
\hline Per capita GDP ratio $\times$ Trade/GDP & & & & $(-0.02)$ \\
\hline Adjusted R-squared & 0.46 & 0.46 & 0.47 & 0.47 \\
\hline
\end{tabular}

regression adds an interaction term of trading partners' growth with the trade share. The results imply that the positive impact on growth from faster growth among trading partners increases with openness, although the estimate of the interaction term is relatively small. ${ }^{18}$ These results are robust if the regression excludes the fixed effects and instead takes the form of a pooled panel estimation (see below). ${ }^{19}$

An interaction term of trading partners' growth with domestic per capita GDP is not statistically significant, suggesting that both rich and poor countries benefit from trading with fast-growing trading partners. An interaction term of trading partners' growth with the level of domestic GDP is also not statistically significant, which is surprising, as it may be reasonable to expect economic conditions abroad to have a larger impact on small than on large countries.

Does the level of per capita GDP in a country's trading partners matter for domestic growth? The empirical evidence suggests that it does. The first regression in Table 4 controls for the average per capita GDP of trading partners; the

\footnotetext{
${ }^{18}$ Specifically, with every 10 percent increase in the trade share, a 1 percent increase in trading partners' growth is correlated with a 0.1 percent increase in domestic growth.

${ }^{19}$ All robustness results cited in this paper are available from the authors on request.
} 
coefficient is positive but not statistically significant. However, the second regression controls for the ratio of a country's per capita GDP to the average per capita GDP of its trading partners; in this case, the coefficient is negative and statistically significant. In particular, a rise in trading partner GDP that lowers the ratio of domestic to foreign GDP by 10 percentage points is correlated with an increase in domestic growth of 0.13 percentage points. This suggests that what matters for a country's growth is not how rich its trading partners are but rather how rich they are relative to the country itself. One interpretation of the result is that a country's speed of conditional convergence depends positively on how advanced its trading partners are relative to itself. As a country closes the income gap with its trading partners, it grows more slowly; alternatively, trade with relatively richer countries is positively correlated with growth. ${ }^{20}$

The last two regressions in Table 4 add interaction terms with the trade share. The interaction term with trading partners' growth has a positive and statistically significant estimate. The interaction term with relative per capita GDP is not statistically significant, which is surprising, as more open countries can be expected to benefit more from higher relative income among their trading partners. ${ }^{21}$ This result can be explained by the fact that even economies with relatively small overall trade shares may benefit from trade with more developed economies through bilateral trade agreements or other arrangements. However, it may also have to do with measurement errors in trying to use the trade share to proxy for trade openness. An interaction term with GDP, rather than per capita GDP, also was not statistically significant.

The results in Table 4 are consistent with the argument that trade fosters growth through spillover effects. The growth and R\&D literature has shown that spillover effects are larger for developing countries that are open to trade, because they benefit from the large knowledge stock of their more developed trading partners. ${ }^{22}$ Since the analysis in this paper uses export weights, the results suggest that, controlling for other growth determinants, countries that export to relatively more advanced countries grow faster. This situation may be driven by specialization in technologically advanced sectors when exporting to a more advanced country, which may also result in positive spillovers to other sectors of the economy. Furthermore, these sectors have a relatively high import content of technologically advanced inputs, especially in developing countries, which may also result in spillover effects. ${ }^{23}$

\footnotetext{
${ }^{20}$ The estimated equation in this case is: per capita GDP growth $=c-c_{1}(y)-c_{2}\left(y / y^{*}\right)+c_{3}$ (other growth determinants), where $y$ and $y^{*}$ represent home and trading partners' per capita GDP levels, respectively. The equation can be rewritten as: per capita GDP growth $=c-y\left[c_{1}+c_{2}\left(1 / y^{*}\right)\right]+c_{3}$ (other growth determinants).

The equation indicates that as a country reaches a higher level of per capita GDP, the negative impact on its growth resulting from convergence forces (the term $\left[c_{1}+c_{2}\left(1 / y^{*}\right)\right]$ ) is smaller the higher is the level of its trading partners' per capita GDP $\left(y^{*}\right)$. The implication is that countries with relatively more developed trading partners should grow faster.

${ }^{21}$ Small countries might be expected to be more open than large countries and, therefore, to be affected more by their trading partners. In addition, since the interaction term of openness with trading partners' growth is significant, it is surprising that the interaction term of openness with size is not also significant.

${ }^{22}$ See Navaretti and Tarr (2000) for a review of the literature on growth and R\&D.

${ }^{23}$ The analysis relies on export weights; in practice, export weights and import weights are often highly correlated because of factors such as regional trade agreements and geography.
} 
Interestingly, the estimates of the trade share are statistically significant only when the interaction terms are excluded from the regression, which suggests that the impact of openness on growth depends entirely on how fast a country's trading partners are growing. However, such a claim would require the caveats that the trade share is only one measure of openness among several and that when the regression is estimated for more recent decades (discussed below) the trade share alone does become statistically significant.

These results might raise a question about whether the significant impact of trading partners' growth on domestic growth simply reflects trends in the regional or global economy that affect all countries. For example, distance is a key determinant of trade in empirical gravity-equation models: controlling for all other trade determinants, countries trade more with others that are close by rather than far away. Thus, the results may capture regional growth trends that may or may not have to do with trade. If the results are indeed driven by such regional trends, only countries that are nearby should matter for a country's growth; after controlling for regional growth, the growth of trading partners should not matter. However, if the results are driven by trade, growth among both regional and other trading partners should matter for growth.

The sign and significance of the coefficients of trading partners' growth and relative income are robust to the inclusion of common regional and global effects, which suggests that trading partners have an impact on growth that goes beyond these effects. Regional trends can be captured by the distance-weighted average growth rate of the rest of the world, with the inverse of the distance between the home country and each of the foreign countries as weights (the closer the foreign country, the larger the weight). ${ }^{24}$ The results of this test are shown in Table 5. Distance-weighted growth in the rest of the world has a positive and statistically significant coefficient of about 0.5 in all specifications, which means that a country's growth is positively correlated with growth in countries that are close to it. This result may be driven by regional trends or by the fact that countries trade more with countries that are nearby. The coefficient of trading partners' growth is now smaller than before (equal to about 0.4 , compared with 0.8 previously), but this should be expected: because countries trade more with countries in close proximity, part of the growth impact from trading partners is now captured by the distance-weighted growth rate.

The correlation between trading partners' growth and regional growth is relatively high, as the gravity model would suggest. A regression of growth of trading partners with distance-weighted growth as an independent variable gives a statistically significant estimated coefficient equal to 0.8 when fixed effects are included and 0.7 when fixed effects are not included. ${ }^{25}$ Despite the high correlation, the

\footnotetext{
${ }^{24}$ The distance between two countries is measured by the distance between their capitals, as reported by the Centre d'Etudes Prospectives et d'Informations Internationales (CEPII). The results are similar if regional growth trends are instead captured by the average growth rate in the continent to which each country belongs.

${ }^{25}$ Using world growth instead of distance-weighted growth as an independent variable results in coefficients of a similar magnitude.
} 


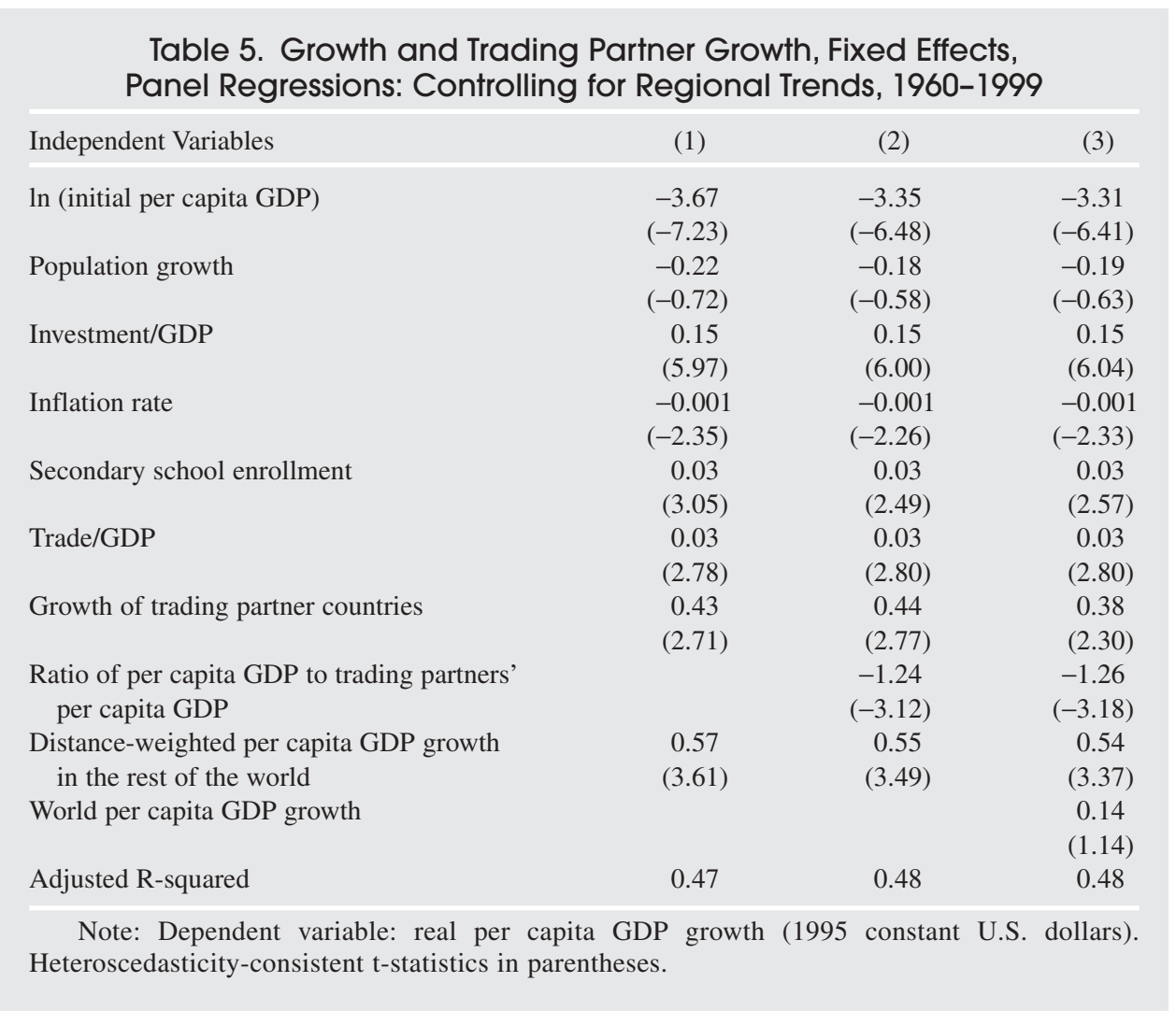

coefficients of both variables are relatively stable in changes of the basic specification. Moreover, the high correlation justifies the use of distance-weighted growth to instrument for trading-partner growth, as is done in the next section.

The coefficient of trading partners' growth is somewhat smaller than the coefficient of the distance-weighted growth in the rest of the world (the difference is statistically significant), which also should be expected, as, again, countries trade more with countries that are relatively close by. The results suggest that even though a substantial part of the impact of trading partners on growth is driven by regional trends (which in turn may be partly driven by trade), trading partners' growth matters beyond regional effects, as its estimate remains economically and statistically significant. World growth is not statistically significant in this specification, implying that once regional and trading partner growth are taken into account, global economic trends do not matter for growth. ${ }^{26}$ The relative income of trading partners remains statistically significant, and its estimate does not change.

\footnotetext{
${ }^{26}$ In addition, the results are not driven by growth only in particular regions. For example, the results do not change if East Asia is excluded from the sample. (Details are available from the authors on request.)
} 


\section{Robustness Tests}

Considering only the period 1980-1999, as shown in the first two regressions of Table 6, results in larger estimated coefficients for both trading partners' growth and relative per capita GDP, although only when the interaction terms are included. The impact of economic conditions among trading partners would be expected to be larger as a result of greater global integration during the past two decades. The world trade share increased from an average of 26 percent in the 1960s to 42 percent in the 1990s; this greater openness could be expected to have a positive influence on spillover effects from trading partners. In contrast with the full-period estimation, the interaction term of the trade share with relative per capita GDP is statistically significant, while the interaction term with trading partners' growth is not significant. The trade share alone is significant, although at the 10 percent level, when the interaction terms are included.

An alternative approach to test whether the impact on growth of economic conditions among trading partners differs according to the degree of openness of

\begin{tabular}{|c|c|c|c|c|}
\hline \multirow{3}{*}{$\begin{array}{l}\text { Independent Variables } \\
\text { ln (initial per capita GDP) }\end{array}$} & \multirow{2}{*}{\multicolumn{2}{|c|}{$\begin{array}{c}\text { 1980-1999 } \\
\text { All economies }\end{array}$}} & \multicolumn{2}{|c|}{ 1960-1999 } \\
\hline & & & Open economies & Closed economies \\
\hline & $\begin{array}{l}-4.92 \\
(-5.78)\end{array}$ & $\begin{array}{l}-5.16 \\
(-6.10)\end{array}$ & $\begin{array}{l}-3.75 \\
(-6.25)\end{array}$ & $\begin{array}{l}-3.31 \\
(-4.05)\end{array}$ \\
\hline Population growth & $\begin{array}{l}-0.48 \\
(-1.71)\end{array}$ & $\begin{array}{l}-0.62 \\
(-2.27)\end{array}$ & $\begin{array}{l}-0.51 \\
(-1.27)\end{array}$ & $\begin{array}{l}-0.12 \\
(-0.30)\end{array}$ \\
\hline Investment/GDP & $\begin{array}{c}0.15 \\
(3.66)\end{array}$ & $\begin{array}{c}0.16 \\
(4.02)\end{array}$ & $\begin{array}{c}0.22 \\
(6.08)\end{array}$ & $\begin{array}{c}0.14 \\
(4.32)\end{array}$ \\
\hline Inflation rate & $\begin{array}{l}-0.001 \\
(-2.39)\end{array}$ & $\begin{array}{l}-0.001 \\
(-2.47)\end{array}$ & $\begin{array}{l}-0.01 \\
(-2.09)\end{array}$ & $\begin{array}{l}-0.001 \\
(-1.56)\end{array}$ \\
\hline Secondary school enrollment & $\begin{array}{c}0.05 \\
(4.13)\end{array}$ & $\begin{array}{c}0.05 \\
(4.01)\end{array}$ & $\begin{array}{c}0.05 \\
(4.86)\end{array}$ & $\begin{array}{c}0.00 \\
(0.02)\end{array}$ \\
\hline Trade/GDP & $\begin{array}{c}0.03 \\
(2.68)\end{array}$ & $\begin{array}{c}0.02 \\
(1.59)\end{array}$ & $\begin{array}{r}0.005 \\
(0.59)\end{array}$ & $\begin{array}{c}0.04 \\
(3.02)\end{array}$ \\
\hline $\begin{array}{l}\text { Growth of trading partner } \\
\text { countries }\end{array}$ & $\begin{array}{c}0.69 \\
(5.27)\end{array}$ & $\begin{array}{c}0.64 \\
(2.91)\end{array}$ & $\begin{array}{c}0.72 \\
(4.43)\end{array}$ & $\begin{array}{c}0.80 \\
(5.31)\end{array}$ \\
\hline $\begin{array}{l}\text { Ratio of per capita GDP to } \\
\text { trading partners' per capita GDP }\end{array}$ & $\begin{array}{l}-0.98 \\
(-1.90)\end{array}$ & $\begin{array}{l}-4.15 \\
(-3.95)\end{array}$ & $\begin{array}{l}-1.20 \\
(-3.65)\end{array}$ & $\begin{array}{l}-1.28 \\
(-0.30)\end{array}$ \\
\hline Interaction term: & & 0.00 & & \\
\hline $\begin{array}{l}\text { Growth of trading partners } \\
\times \text { Trade/GDP }\end{array}$ & & $(0.24)$ & & \\
\hline $\begin{array}{l}\text { Interaction term: } \\
\text { Per capita GDP ratio } \times \text { Trade/GDP }\end{array}$ & & $\begin{array}{c}0.04 \\
(3.85)\end{array}$ & & \\
\hline Number of economies & 101 & 101 & 31 & 70 \\
\hline Adjusted R-squared & 0.50 & 0.51 & 0.63 & 0.37 \\
\hline
\end{tabular}


the economy is to separate the sample into "open" and "closed" economies, as in the last two regressions of Table $6 .{ }^{27}$ In these regressions, economies that meet the Sachs-Warner definition of openness for at least two decades during 1960-1999 are characterized as open (31 countries), and the rest are characterized as closed (70 countries). The estimate for trading partners' growth is positive and statistically significant for both groups. It is 0.7 for open economies and 0.8 for closed economies, although the difference between the two estimates is not statistically significant. This is a surprising result, especially given that the estimate of the interaction term of growth in trading partners with the trade share in Table 4 suggested that open economies benefit more from fast-growing trading partners. One possibility is that countries that are categorized as "closed" may, in fact, trade significantly with a particular country (as the former French colonies in Africa do with France) and may thus be influenced by its growth. The estimated coefficient for relative per capita GDP is significant only for open economies, as one would expect.

The results are robust to estimation using instrumental variables. Consistent with the approach of Frankel and Romer (1999), distance-weighted growth in the rest of the world is used as an instrument for growth in trading partners. This approach addresses the potential causality concern that the results simply reflect the case of fast-growing countries exporting to other fast-growing countries. The results in the first three columns of Table 7 (from a pooled regression for the period 1960-1999 and for the subperiods 1960-1980 and 1980-1999) confirm the positive impact on domestic growth of growth among trading partner countries.

The results are also robust in a cross-section estimation that uses averages for the subperiods 1960-1980 and 1980-1999, and in a panel regression that uses 10 -year averages instead of 5-year averages. These results are shown in the last four columns of Table 7 . The results relate to the basic specification but hold when all other specifications mentioned above are used instead. The estimated coefficient of trading partners' growth remains statistically significant and close to the previous estimates.

\section{Conclusion}

This paper asks a somewhat different question than the one usually asked in the growth-openness literature. Specifically, the paper examines whether economic conditions in a country's trading partners matter for its growth. On the basis of a fixed-effects panel estimation using data for 101 countries during 1960-1999, the results suggest that a country's growth is positively associated with both the growth rates and relative incomes of its trading partners.

\footnotetext{
${ }^{27}$ Sachs and Warner (1995) define an economy as "open" if all five of these conditions hold: (1) the average tariff rate is less than 40 percent; (2) the average nontariff barriers are less than 40 percent; (3) the black market premium is equivalent to less than 20 percent of the official exchange rate; (4) the government is not communist; and (5) there is no state monopoly on major exports. As noted in the literature review section, Rodriguez and Rodrik (1999) have criticized this approach. However, Warner (2002) has responded to their criticism with evidence in support of this approach.
} 


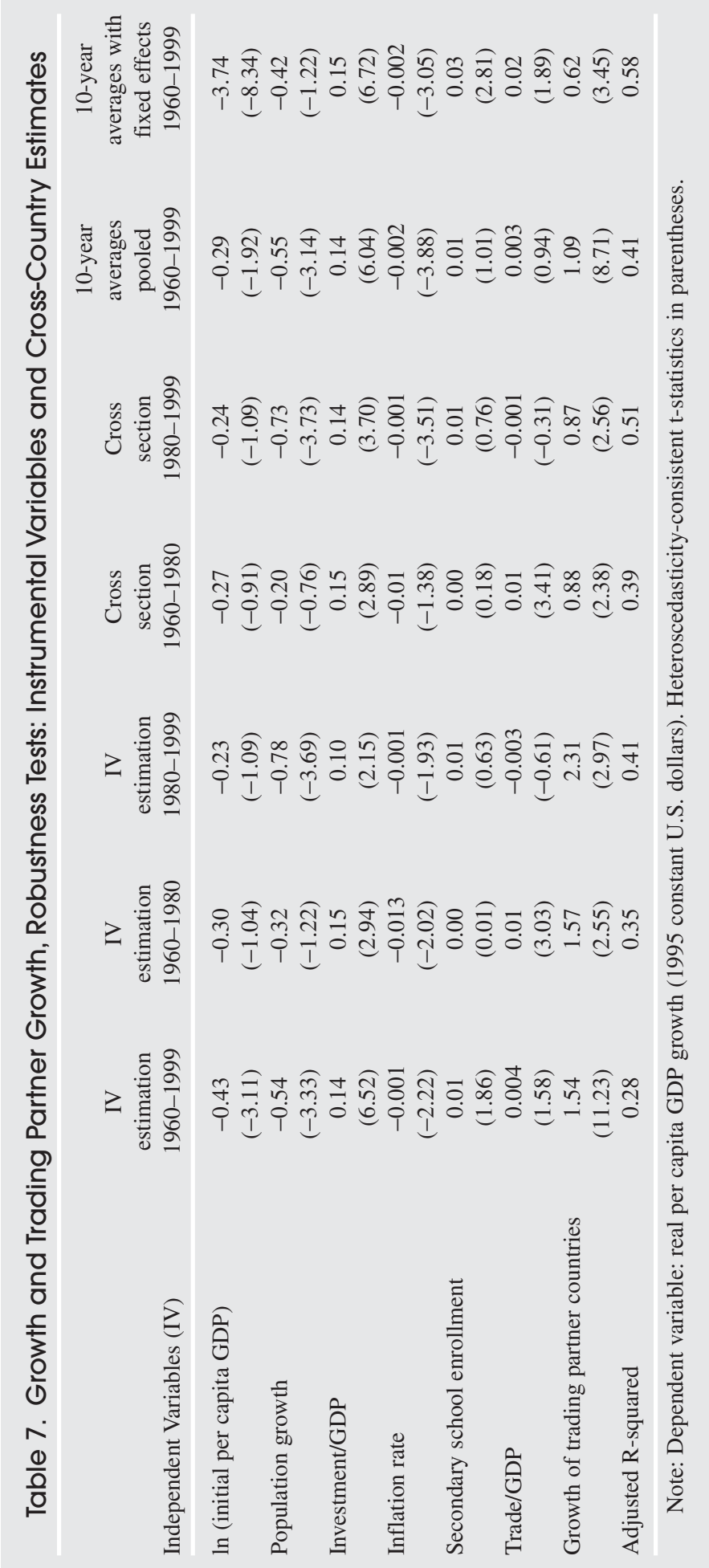


A general implication of the results is that countries benefit from trading with fast-growing and relatively richer countries. These results are not driven by common global trends, as they hold even after controlling for world growth and for growth in nontrading partner countries. Neither are they driven by regional shocks, as they hold after controlling for a distance-weighted growth of the rest of the world. The results also are not driven by reverse causality, because they are robust to estimation using distance-weighted growth to instrument for trading partners' growth and are robust to a number of alternative specifications and robustness tests. The results seem to be stronger for open economies in some specifications and for more recent decades.

\section{REFERENCES}

Agenor, Pierre-Richard, John McDermott, and Eswar Prasad, 1999, "Macroeconomic Fluctuations in Developing Countries: Some Stylized Facts," IMF Working Paper 99/35 (Washington: International Monetary Fund).

Ahmed, Shaghil, and Prakash Loungani, 1999, "Business Cycles in Emerging Market Economies," Monetaria, Volume XXII (October-December), Centro de Estudios Monetarios Latinoamericanos (CEMLA).

Arora, Vivek, and Athanasios Vamvakidis, 2004, "The Impact of U.S. Economic Growth on the Rest of the World: How Much Does It Matter?" Journal of Economic Integration, Vol. 19 (March), pp. 1-18.

Baldwin, Robert E., 2003, “Openness and Growth: What's the Empirical Relationship?” NBER Working Paper No. 9578 (Cambridge, Massachusetts: National Bureau of Economic Research).

Barro, Robert, and Xavier Sala-i-Martin, 1995, Economic Growth (New York: McGraw Hill).

Ben-David, Dan, 1993, "Equalizing Exchange: Trade Liberalization and Income Convergence," Quarterly Journal of Economics, Vol. 108 (August), pp. 653-79.

Bhagwati, Jagdish N., and T. N. Srinivasan, 1985, "Trade Policy and Development," in Dependence and Interdependence, Essays in Development Economics, Vol. 2, ed. by Gene Grossman (Cambridge, Massachusetts: MIT Press).

— 2002, "Trade and Poverty in Poor Countries," American Economic Review, Vol. 92 (May), pp. 180-83.

Brunner, Allan D., 2003, "The Long-Run Effects of Trade on Income and Income Growth," IMF Working Paper 03/37 (Washington: International Monetary Fund).

Caselli, Francesco, Gerardo Esquivel, and Fernando Lefort, 1996, "Reopening the Convergence Debate: A New Look at Cross-Country Growth Empirics," Journal of Economic Growth, Vol. 1 (September), pp. 363-89.

Clemens, Michael, and Jeffrey Williamson, 2004, "Why Did the Tariff-Growth Correlation Reverse After 1950?" Journal of Economic Growth, Vol. 9, No. 1, pp. 5-46.

Coe, David, and Elhanan Helpman, 1995, "International R\&D Spillovers," European Economic Review, Vol. 39, No. 5, pp. 859-87.

— , and Alexander Hoffmaister, 1997, "North-South R\&D Spillovers," Economic Journal, Vol. 107 (January), pp. 134-49.

Dollar, David, 1992, “Outward-Oriented Developing Economies Really Do Grow More Rapidly: Evidence from 95 LDCs, 1976-1985," Economic Development and Cultural Change, Vol. 40 (April), pp. 523-44. 
Economist, The, 2002, “United We Fall,” September 26.

Edwards, Sebastian, 1998, "Openness, Productivity and Growth: What Do We Really Know?" Economic Journal, Vol. 108 (March), pp. 383-98.

Frankel, Jeffrey A., and David Romer, 1999, "Does Trade Cause Growth?” American Economic Review, Vol. 89, No. 3, pp. 379-99.

Greenaway, David, Wyn Morgan, and Peter Wright, 1998, "Trade Reform, Adjustment and Growth: What Does the Evidence Tell Us?" Economic Journal, Vol. 108 (September), pp. 1547-61.

Harrison, Ann, 1996, "Openness and Growth: A Time-Series, Cross-Country Analysis for Developing Countries," Journal of Development Economics, Vol. 48 (March), pp. 419-47.

International Monetary Fund, 2002, Direction of Trade Statistics Yearbook (Washington: International Monetary Fund).

Levine, Ross, and David Renelt, 1992, "A Sensitivity Analysis of Cross-Country Growth Regressions," American Economic Review, Vol. 82 (September), pp. 942-63.

Navaretti, Giorgio Barba, and David Tarr, 2000, "International Knowledge Flows and Economic Performance: A Review of the Evidence," World Bank Economic Review, Vol. 14 (January), pp. 1-15.

Rodriguez, Francisco, and Dani Rodrik, 1999, “Trade Policy and Economic Growth: A Skeptic's Guide to the Cross-National Evidence," NBER Working Paper No. 7081 (Cambridge, Massachusetts: National Bureau of Economic Research).

Sachs, Jeffrey D., and Andrew Warner, 1995, "Economic Reform and the Process of Global Integration," Brookings Papers on Economic Activity: 1, Brookings Institution, pp. 1-95.

Spilimbergo, Antonio, 2000, "Growth and Trade: The North Can Lose," Journal of Economic Growth, Vol. 5 (June), pp. 131-46.

Vamvakidis, Athanasios, 1998, "Regional Integration and Economic Growth," World Bank Economic Review, Vol. 12 (May), pp. 251-70.

— 1999 , "Regional Trade Agreements or Broad Liberalization: Which Path Leads to Faster Growth?" IMF Staff Papers, International Monetary Fund, Vol. 46, No. 1, pp. 42-68.

- 2002, "How Robust Is the Growth-Openness Connection? Historical Evidence," Journal of Economic Growth, Vol. 7, No. 1, pp. 57-80.

Warner, Andrew, 2002, "Once More into the Breach: Economic Growth and Global Integration" (unpublished; Cambridge, Massachusetts: Harvard University).

World Bank, 2002, World Development Indicators (Washington: World Bank). 